\title{
Discussion on Emotion Cultivating of Vocal Music Education
}

\author{
Lili $\mathrm{Fu}$ \\ Department of Art \\ Hainan College of Software Technology \\ Qionghai, Hainan, China \\ e-mail: 3701911@qq.com
}

\begin{abstract}
The soul of vocal music education is emotion cultivating which also plays an important role during the process of vocal music education. Repetiteur needs to teach student to integrate own emotion into vocal music performance during the practicing process through emotion cultivating, and to further understand songs during the emotion changing process, then achieving the ability improvement of vocal music performance. This paper mainly illustrates the importance of emotion cultivating during the vocal music education, and further studies how to integrate emotion education into vocal music education.
\end{abstract}

Keywords-vocal music education; emotion cultivating; important; integrate

\section{INTRODUCTION}

Famous music educator Herbert Zipper has once said: "human's expression of the outside world needs science, also arts in the expression of inner feelings, and music can best express human feelings directly, even more directly than language." In vocal music teaching, proper infusion of the emotional education not only can improve students' ability to appreciate the vocal music works, also can make the student improve the expression of true feelings in the singing of vocal music works in the process of feeling true feelings of works.

Although scientific singing enables sound itself with rich artistry, which has embodied the artistic value of the human, the connotation of emotional expression in singing and the resulting aesthetic experience is more crucial. Emotion occupies an important place in music education and music performance, also wining increasing attention from insiders. Hence, emotional cultivation is particularly important in the vocal music education.

\section{The Main CONTENT OF EMOtional Cultivation IN THE VOCAL MUSIC EDUCATION}

\section{A. Feeling expressed by voice}

Vocal music works can neither perceive works through vision, nor directly understand the purpose and intention of the creator. "Silence" and "static" of vocal music renders freedom of second creation to singer. The audience can't directly feel and appreciate the stillness of the music, and the silent note must be inverted by the singer into music image of "excellent voice and affection", and only to better express feeling through voice can meet the needs of the audience [1].

The singer, in the expression of works, needs to be on the basis of respect and loyal to the original, and then according to their own understanding of the work, makes artistic polishing, with close integration of vocal music skills and art of conveying emotions. A singer, to fully show artistic appeal of the work, needs to correctly understand the connotation of lyrics based on understanding of the creators' style and historical background, and to fully understand the motive of his works and the thoughts and feelings. Then exerting individual subjective initiative, combined with singing skills and self-emotion, the singer conveys the feeling with voice, transferring "silent" work into vivid image of music, so as to more realistically portraying deep artistic conception of works in the form of "feeling expressed by voice".

During the Song, Yuan, Ming and Qing dynasties, China's aesthetic ideology of vocal music art has been mature. Music is the expression of emotion, directly deducing people's rich psychological changes and emotional life, and only the music revealing true sentiments is charming. In the late Ming Dynasty, Zhangqi's theory monograph Heng Qu Zhu Tanp has raised emotion to a new height, and put forward the relationship between sound and emotion that" singing is one of the main means of opera performance and connotation beauty can be achieved by blending feeling and setting". As the outstanding representative of the singing theory, both $\mathrm{Xu}$ Dachun's "Talking Drums in Yueh-Fu", and Li Yu's "Occasional Enjoyment " reflect the tendency of universal thought of traditional Chinese vocal music aesthetics -- it requires free lyric in singing, to facilitate better service to the emotion, with "feeling" throughout the show, so as to achieve excellent voice and emotion.

Since the reform and opening up, many songs with individual emotions fully liberated is popular among the ordinary people, and illustrious songs of different emotions and individual characters are widely promoted, including "The party, Oh Dear Mother", " Cordiality of Green Leaf to Root", "Thousand-Time Asking", "On The Hopeful Field", 
"Coming Home" and "Longing" and so on, which has also reflects the emotional expression of great number of creators and masses in the vocal music art - stress of "expressing emotion through voice".

Famous song of Olive Tree, with graceful melody and rich thought connotation, has strong artistic appeal and artistic tension. Many singers have sung the song, but Chyi $\mathrm{Yu}$ perfectly deduces this piece of work and highly recognized by the audience because of "fusion of voice and emotion".

\section{B. Driving voice with emotion}

To affectionately deduce a song, it needs singer's comprehensive thinking, taste and scrutiny, the process of gradually experiencing meaning, the theme and artistic conception, which is namely the process of driving voice with emotion. The core of vocal music art creation is emotional expression, in which excellent voice and emotion, and to express emotion through voice is the basis of emotion in the acoustic performance. With the perfect combination of both, as to vocal music art, if there is no expression of emotion, the soul of singing would be lost, thus it cannot be called as the creation of vocal music art ${ }^{[2]}$.

In the training of students, it is found that some students is quite good in terms of voice condition, also mastering the scientific voice and singing skills, but in singing, they are unable to do as well as they would wish, and there's no way to show the charm of songs. That is because that they does neither have enough understanding of the work, nor understand the artistic conception and the connotation of work, or lacking in life experiences and emotional experience and so on, which results that they can't achieve the perfect combination of sound and emotion. In our country, a lot of music works take poems as the creation background, thus the literariness of lyrics itself also requires the combined application of literature and art in the creation of vocal part. These works have deep thoughts and rich emotion connotations. As to the singer, in dealing with these vocal music works, first of all, they should fully understand literature content and ideological content of works, and vivid feeling can only be achieved by a wholehearted commitment. To deduce works by driving the voice with emotion, and to make a secondary high-level interpretation of works, can finally realize the harmony of feeling and sound.

\section{THE IMPORTANT VALUE OF EMOTIONAL CULTIVATION IN VOCAL MUSIC EDUCATION}

In ancient times, there was the expression that "the sound is out of the feeling", "emotion is the foundation of sound, and the sound is the form of emotion", which shows that the ancients had summarized the truth that there could be voice when there is sentiment; sentiment is produced by human; human is touched by the sentiment. The classic expression that "the tune lingers in the house" stems from the praise to a female singer called Han E in the Warring States Time, and this shows the importance and its influence of emotional resonance in the singing ${ }^{[3]}$.
China's first "full-time compulsory education music course standard" claims "music aesthetic as the core" in the music class, and requires that while teaching music knowledge and skills, vocal music teachers should lay emphasis on music emotion experience, making the students' emotional world infected and influenced, and treat the teaching of emotional expression as an important link. Vocal music education has united knowledge, skills and practice, and it is required to enable students to have a higher level of vocal music singing through theoretical teaching of music technique in the process of teaching. If it is lacking in emotional cultivation in the process of teaching, even if the students' theoretical level reaches a certain degree, they appear to only hear the voice in terms of their performances, but unable to resonate.

Vocal music art is a kind of art that stimulates the emotions. With scientific vocal skills in the process of singing, clear enunciation, and processing skills in voice and tone, but without narration of emotion, it is impossible to deduce vocal music works perfectly. The important factor affecting the singer's voice quality and the resonance with the audience is the emotion, and the vocal music performance with emotional performance can only be called music beauty. Emotional expression plays a very important role in vocal music performance. Poet Bai Juyi has once said that: "the sound is the performance of musicians, and the emotion is the performance of singers".

\section{APPROACHES TO THE EMOTIONAL CULTIVATION IN VOCAL MUSIC EDUCATION}

\section{A. Emotional experience}

Any form of art deviating from life is unable to be formed, and any art form is the result after the expression, refining and processing of real life, and artistic work deviating from the real life is like a tree without roots, water without a source, unable to be handed down permanently. Vocal music work is also the same case. Each work is creator's experience, refining and processing, of life and then a vocal music work known and popular with the general public is created to meet the audience's music aesthetic demand. For instance, widespread songs of "Eighteen curve of hill path", "Qinghai-Tibet Plateau" and "Kashgar girl" are excellent works of vocal music based on the folk and then created. These works coming from social life carry five thousand years of civilization of the Chinese nation, adhering to the people's common pursuit of art, thus they can be widespread and popular.

The transfer of truth in vocal music work is based on real emotional experience in life, and as a vocal performer, only when he is attracted by emotional expression in the song, with profound emotional experience in his own mind, a fascinating artistic conception can be created to infect the audience. In teaching process, while instructing the professional theory and skill knowledge, vocal music teachers also should pay attention to cultivating students' consciousness of observation and experience. Feelings in real life can be personal experience, the emotional experience drawn from friends and family, also indirect understanding 
and learning acquired from film, drama and novel, so as to receive more complicated emotional experience of people. The deeper the experience is, the richer the expression will be, and the supreme state of the singing art can be shown.

Emotional experience can also draw support from modern means of multimedia. For instance, teachers can play students vocal music works with different style, in different times, and of different schools, enabling students to understand the differences in the emotional expression of different types of songs, to further induce the students' emotional experience. For example, when giving a lesson on Schubert's artistic work of "Trout", teachers can show the setting on the screen that trout swims in the stream leisurely. This work indicates the profound implied meaning of the lyrics using narrative mode of strophic song. Namely, kind and innocence tend to be hurt by false fraud and evil, which shows his unlimited sympathy and pity for the fate of trout. Visual and sound effects obtained through forms of sound, effect and animation, etc can arouse students' affection for fish and in this way, students can manifest the author's inner world when singing, from the quiet freedom, concerns finally evolved into sympathy and pity, with layer upon layer development.

Regardless of direct or indirect emotional experience, the ultimate aim is to enrich students' emotional experience, to make it easier for the students to "go into emotion", and "to go into setting". Rich emotional experience is a significant way to improving students' emotional expressiveness.

\section{B. Analyze creation background of works}

Each vocal music work is completed in a particular context, with its specific emotions, but before there is no indepth analysis, students are difficult to understand and experience the true feelings that the work tries to express. Even some students give full play to the imagination, with clear cognition, but it is still difficult to master the real emotional experience, and as for such a deduction, it is difficult to finish the secondary creation of the work ${ }^{[4]}$. For the analysis of the work, students must be made clear of creation background of the work, either the expression of anger, hatred, or joy, great love to the people or the tiny romanticism of small love, patriotic praise or hatred of invaders. Students' emotion can be effectively stimulated through stories, short film and other forms, so as to be better integrated into the work, and to make commendable play of the vocal music works.

For instance, when making the work of The Butterfly Lovers, teachers can encourage the students to watch the movie, drama or dance clips by the same name, bringing students into story context, so as to feel the pure beautiful love and pain of part for ever. Also, students can fantasy wonderful fairyland, experiencing the rich emotion and background behind the work with multi-angle feelings, touched by Butterfly Lovers' courage to pursue true love, thus stimulating students' inner desire of expression.

The story of Meng Jiangnv bringing down the Great Wall with tears is widely spread in the forms of drama, song, poem, rap, etc, and it may become a household word.
According to legend, in the First Emperor of Qin period, with difficult labor, young men and women Fan Qiliang and Meng Jiangnu had just got married for three days, the groom was forced to start to build the Great Wall, soon died of cold and exhaustion, with skeleton buried under the Great Wall. She cried under the Great Wall for more than three days and three nights, thus the Great Wall was cracked down, revealing the skeleton of Fan Qiliang, and then Meng Jiangnu jumped into the sea in the despair and death. Since then, Shanhai Pass is considered by later generations as the place of Meng Jiangnv bringing down the Great Wall with tears, and the Meng Jiangnu temple is built there, people coming and going here often shed tears of sympathy. Folk song of Meng Jiangnu is acted under such a story, and as to the analysis of the background for this piece of work, it must be based on the background of the story, making the singer realize expressing intentions of stretch, tardiness, euphemism, sadness, dreariness, and intensity in the melody, to more deeply understand the intentions of the work, and then its deep expression of artistic conception can be better sung ${ }^{[5]}$.

The ancients have once said that: a better understanding result in more profound love. Because of this, by analyzing the creation background of the work, teachers, in vocal music teaching, make students' understanding of the work reach a higher level of cognition, inducing the students 'desire of narrating emotion, thus students can do better in the emotional expression in the performance of work.

\section{Promote artistic accomplishment}

Fadeyev, a Soviet writer has once said that: "knowledge is of great help for any type of work, but for the artist, comprehensive education and profound knowledge is more necessary, if you want to be a true expression of life." [6] To improve artistic accomplishment, it cannot be made in one day. To see more, read more, listen more, to have more attempts of contacting the music in various ethnic groups and various schools of art, and to cultivate a wide range of interests and hobbies, aims to sublimate in every bit of accumulation. Improvement of the students' artistic accomplishment shall be started from the literary accomplishment, body language, drama culture, music appreciation step by step with gradual advancement.

Many vocal music works themselves are the combination of literature and art ${ }^{[7]}$, such as Ulysses' homecoming, Prelude to Water Melody the Mid-Autumn festival, and Qinyuanchun, The Marriage of Young Blacky and so on, and these are all accomplished with literary works such as novels, poems, or prose as a background or carrier. For instance, as to The song of burying flower, for singers who have never read A Dream in Red Mansions, although they can understand the feelings of sadness, they can't imagine the illdefined mood and too deep for tears of Lin Daiyu and other women in the grand view garden in the historical environment at that time, thus they also can't sing incisively and vividly, unable to arouse strong sympathy from the audience. So the singers should read more helpful literature, which can not merely edify sentiment, also enrich their own emotional world. With rich emotional world, at the time of deducting works, as for either happy or sad emotion, or too 
deep for tears, they can quickly go into the work and sing in a carried way, so as to achieve better singing effect. Hence, literary accomplishment used to improve students can make their singing career go better and further.

Good vocal performance, in addition to emotional telling, about also needs the appropriate physical actions to strengthen the expressive force of vocal music emotion. No matter it is happy, sad, or passionate song, if coupled with the appropriate physical expression, the singing can be more vivid ${ }^{[8]}$. In the teaching, teachers can let the student convey the music emotion through the learning of folk dance, modern dance, classical ballet and other dances, thus improving power of expression through their body language.

Someone has once said: "the viewer inverting the music of the auditory feeling into emotional experience in his own mind should regard the right music perception as the prerequisite, while when the viewer is not familiar with music sound and its art style, and can't conduct correct music perception, and then he cannot get the right emotional experience." Hence, the improvement of music accomplishment need to be accomplished on the basis of listening more and appreciating more outstanding works, and the appreciated works of art include opern, opera, drama, plays, the living theatre, original movie and others of different themes and contents. Through long-term training and edification, students' music accomplishment can be further improved, and there would also be a qualitative leap in emotional feelings and performance ability of music.

\section{Stimulate students' imagination and creativity}

Singers' vocal music singing is the process of demonstrating art through "instruments" of their own. The vitality of vocal music works is given in the process of singing, also a recreation process of vocal vitality. If there is no creativity and imagination, the vitality of vocal music works cannot be endowed. For the students of vocal singing, cultivation of imagination and creativity is crucial.

Imagination is illusory, but also a crucial psychological regulation factor throughout the process of vocal singing. Singers' emotional experience, background understanding and the expression of work is inseparable from their own imagination. Teacher can guide the student to associate and imagine in the process of abstract and boring vocal music study, so that the students can gradually learn to control their own voices in the process of training, or in a resounding, storytelling, pathetic and touching way, thereby obtaining the ideal sound. It requires students' imagination as to affection, context and people of the song, so as to make better understanding and interpretation of the work. Singers dominate the sound by imagination in singing, and before making voice, and they have orientated the volume, timbre, location, etc., in their minds by imagination. Later, quality of singing after sound production is controlled by imagination completely. Italian singer of Luciano Pavarotti has said: "before sound production, I am just ready to phonate; the voice not sung yet has reached my ears, and I know its condition." $[9]$
With imagination, coupled with the singer's psychological creation ability, exceedingly bright and intense expression of emotion can be made in a second creation to inspire audiences. As to the cultivation of student's creativity, teachers should encourage students to think, discuss, rethink and rediscuss the same question from different angles, and that cycle repeats. Then the student's creativity and inspiration will be embodied slowly, and can be sublimated after precipitation and accumulation. At the same time, cultivation of artistic creation ability also needs constant testing through practices on stage, thus higher artistic achievement can be made in the emotional performance of singing.

Whether it is imagination and creativity, as long as they are excavated by the singer, they would become the infinite power, and the singer can more perfectly shape the image of singing art, which make appreciator obtain sensuous appeal and enjoyment.

\section{CONCLUSIONS}

In short, in the vocal music education, while paying attention to skills, emotional cultivation in the vocal music education is a task that cannot be ignored, but how to truly realize the perfect combination with emotional education in practice has been discussed by vocal music teachers. This paper, combined with teaching practice experience of my own, has made some shallow thinking and exploration of emotional education in music education, aimed at implementing common exploration with the general music education workers to achieve better teaching effect.

\section{REFERENCES}

[1] Li Yanjun Exploration of the emotional cultivation in the process of vocal music teaching. [J]. "Vocational \& Technical Education Forum" 2012, 12:47-48

[2] Tian Qing. On emotional expression in vocal music teaching in normal universities [D]. Hebei, Hebei university, 2009:26-31

[3] LeiQian. Moving people by feelings and touching people by sound Simple analysis of emotional cultivation in vocal music teaching [J]. Teaching beacon, 2010, 5:

[4] Yang lei. Brief analysis of emotional cultivation in college vocal music education [J].Music Magazine, 2014, 2:349

[5] Huang Mingcong. Introduction to middle school students' emotional cultivation in vocal music teaching $[\mathrm{J}]$. Popular literature and art, 2009, 11:196

[6] Zou Changhai. Vocal music art psychology [M]. People's music publishing house, 2000:89

[7] Dong Juan. Literature accomplishment and singing - On the relationship between singer's literature accomplishment and singing [J]. Science and technology education, 2011, 10:180-182

[8] Shang Xuegeng. How to practice singing [M]. People's music publishing house, 2011, 4:58-60

[9] Xing Weikai. Aesthetic course of emotional art [M]. Shanghai music publishing house, 2004, 7:120-125 